\title{
The Main Methodological Approaches to the Personal-Creative Development of Elementary School Pupils in the Process of Music Education
}

\author{
Hou Yimei \\ ORCID https://orcid.org/0000-0002-8435-4345 \\ Postgraduate student (China) \\ Dragomanov National Pedagogical University (Ukraine, Kyiv)
}

\begin{abstract}
In the article the importance of personal and creative development of elementary school pupils in the process of teaching music is actualized. The views of scientists on this problem are investigated and generalized. The author's understanding of the creativity of elementary school pupils is presented. The issue of aesthetic orientation of pupils' creative activity in the process of learning music is emphasized. The role of pedagogical leadership in the educational process for the development of creative abilities of elementary school pupils is emphasized. The main methodological approaches to the personal-creative development of elementary school pupils in the process of teaching music are considered. Applying a personal approach contributes to the identification and disclosure of the personal potential of pupils, the establishment of subject-subject relationships. It is noted that the creativity of students is manifested in educational activities, so for the personal and creative development of younger students in the process of teaching music is important to use the activity approach. An integrated approach provides students with a holistic picture of the world, solving musical and creative tasks with the knowledge of all subjects of the aesthetic cycle and other subjects.

Key words: music teaching, creativity, development, elementary school pupils, personal approach, activity approach, integrated approach.
\end{abstract}

Актуальність дослідження. Результат діяльності вчителя в процесі навчання музики молодших школярів ми вбачаємо (в контексті процесів реформування освіти в Україні, які спрямовані на становлення особистості учня, здатної до творчої діяльності, саморозвитку та самовдосконалення на шляху до мети) в їх особистісно-креативному розвитку, що набуває на сучасному етапі особливої актуальності. Особистіснокреативний розвиток людини вчені пов'язують 3 розумінням природи здібностей та механізму їх розвитку у процесі діяльності.

Питання здібностей розглядалися вченими з найдавніших часів, зокрема праці Аристотеля, Платона, Спінози поклали початок вивчення означеної проблеми у філософському аспекті. У психологічному аспекті питання здібностей висвітлювали I. Бех, В. Бутенко, Е. Клапаред, Г. Костюк, Е. Мейман, Ч. Спірмен, В. Штерн та інші науковці. Взаємодію трьох напрямків: психології діяльності, психології здібностей $\mathrm{i}$ проблеми їх розвитку розглядав В. Шадриков. У соціальному та діяльнісному аспектах 
питання здібностей розкривали В. Дружинін, Л. Виготський, С. Рубінштейн, К. Платонов, Б. Теплов.

Проблему творчих здібностей та розвитку творчої особистості, розглядали В. Клименко, А. Козир, О. Кульчицька, О. Лук, О. Музика, Я. Пономарьов, Т. Равлюк, В. Роменець, О. Савченко, В. Сухомлинський та ін.

Питання креативності досліджувалися багатьма науковцями, зокрема: Д. Богоявленською, Е. де Боно, Дж. Гілфордом, В. Дружиніним, Є. Ільїним, А. Маслоу, В. Моляко, Л. Петько, Р. Стернбергом, Е. Торренсом, В. Юркевич.

Вченими (Л. Божович, Л. Виготський, В. Давидов, Л. Дранков, Д. Ельконін та ін.) підкреслено сенситивність молодшого шкільного віку для креативного розвитку дітей, для художньо-творчого розвитку (С. Жупанин, А. Мелік-Пашаєв, А. Щербо) та музично-творчого (Л. Беземчук, Т. Дорошенко, К. Орф, 3. Рінкявічюс, Т. Тютюннікова, О. Щолокова та ін.). Увагу інших сучасних науковців привертає проблема розвитку творчих здібностей у процесі навчальної діяльності (Н. Волошина, Л. Момот, Л. Шелестова та ін.).

Але, незважаючи на вагомий теоретичний та практичний внесок у вирішення проблеми розвитку творчих здібностей у процесі навчальної музичної діяльності (О. Коваль, О. Лобова, Л. Масол, Е. Печерська, В. Рагозіна, О. Хижна та ін.), до сьогодні існує протиріччя між прогресивною музично-педагогічною теорією та іï впровадженням у практику шкільної музичної освіти. Подальшого вивчення потребують питання особистісно-креативного розвитку молодших школярів у процесі навчання музики.

Метою статmі є визначення методологічних підходів до особистіснокреативного розвитку молодших школярів у процесі навчання музики.

Виклад основного матеріалу. Основний напрямок змін у змісті освіти в Україні згідно з положеннями «Нової української школи» передбачає орієнтацію на ключові компетентності випускників школи [6]. У процесі набуття ключових компетентностей формуються вміння мислити критично і системно; уміння обгрунтовувати і відстоювати свою позицію; комунікативні вміння, спрямовані на здатність працювати у команді; розвиваються творчі здібності. 
За Л. Виготським, розвиток творчої особистості передбачає єдність навчання та внутрішніх процесів розвитку: формування особистості, яка набуває нових якостей відбувається тоді, коли орієнтується «не на вчорашній, а на завтрашній день дитячого розвитку» [1, с. 234]. Концепція Л. Виготського про «зону найближчого розвитку» грунтується на педагогічному керівництві процесом подолання відстані між наявними можливостями та потенційним рівнем розвитку дитини в процесі навчання, що особливо актуально для молодшого шкільного віку. В цей період діти ще прагнуть наслідувати дорослих, для них вчитель - беззаперечний авторитет. Важливо тільки, щоб те наслідування було осмисленим. Цьому сприяють вікові психологічні особливості молодших школярів: водночас із «слухняністю» (Н. Лейтес) у них швидко збільшується обсяг мислення, розвиваються переключення, вибірковість.

Із віковими особливостями дитини пов’язано і твердження О. Савенкова про те, що основним фактором розвитку креативності дитини є не стільки його включення в креативну діяльність, скільки наявність в його оточенні «зразка креативної діяльності» [10].

Отже, розвитку креативних здібностей молодших школярів сприяє педагогічне керівництво навчальним процесом. Якщо у дітей віком 3-5-ти років прояв творчості є природною потребою (Д. Богоявленська, Е. Торренс, В. Юркевич), і 3 13-ти розвиваються схильності до певного роду занять (спеціальні здібності), то період, який називається молодшим шкільним віком, треба максимально використати для особистісно-креативного розвитку. Науковці відзначають залежність розвитку творчих здібностей у процесі навчання молодших школярів «не тільки від низки внутрішніх факторів (психофізіологічні та соціальні надбання, інтелектуальний, практичний та емоційний досвід дитини), але і зовнішніх (наявність відповідної системи й навчальних програм, педагога-творця і відповідного педагогічним запитам розвивального середовища)» [5, с 84].

Одним з основних завдань оновлення освітнього простору, вважає I. Лапшина, розглядаючи шляхи формування творчих здібностей молодших школярів, потрібно вважати «максимальне створення комфортних умов для становлення і розвитку творчої особистості юних громадян, оскільки саме такі особистості швидше і легше адаптуються до соціальних та виробничих новацій, ефективніше їх використовують для 
задоволення власних потреб і можливостей, а з часом - для розвитку всього суспільства у цілому» [4, с. 108].

У зв'язку з цим на чільне місце виходить проблема виокремлення методологічних підходів до розв'язання проблеми особистісно-креативного розвитку молодших школярів у процесі навчання музики, як складової їх мистецької освіти.

Мистецтво в концептуальних державотворчих документах розглядається як суттєвий компонент загальної освіти, що сприяє розвитку музичної культури як частини загальної культури школярів. Саме цілісність сприймання культурного простору «в його багатогранності і художній образності»є метою уроків мистецтва у закладах загальної середньої освіти. Що стосується уроків музичного мистецтва, вони покликані навчити дітей повноцінного спілкування з музикою, при якому «відбувається виникнення художньо-образних асоціацій, стимуляція уяви, фантазії, емоційночуттєвого ставлення до музичних творів, збагачується суб'єктивне світовідчуття і світосприймання, розвивається емоційна й інтелектуальна сфери особистості тощо» $[11$, с. 2]. Як зазначає Л. Степанова, увесь цей комплекс повинна розвивати уже початкова ланка музичної освіти. Адже кінцевою метою музичних занять $є$ формування музичної культури учня як частини його духовної культури (Д. Кабалевський).

Навчання музики передбачає наявність музично-творчої діяльності. У процесі цієї діяльності формуються особистісні якості молодших школярів, чим забезпечується їхній особистісно-креативний розвиток. Творча діяльність сприяє подальшому розвитку в учнів креативності як «ядра ії особистості» (С. Сисоєва).

Креативність як загальну здатність до творчої діяльності розуміють науковці Я. Пономарьов і В.Дружинін [6; 2]. Проте, на основі загальної розвивається спеціалізована креативність - здатність до творчості у визначеній сфері людської діяльності [3; 7; 8; 14 ; $15]$.

Креативність молодшого школяра ми розуміємо як здатність до конструктивного, нестандартного мислення, яка, на основі набуття особистістю різнобічних знань, усвідомлення власного досвіду, в процесі творчої діяльності уможливлює створення нового.

Наявність творчих можливостей $є$ головним показником становлення особистості. Рівень розвитку індивида проявляється через творчий розвиток, потребу в 
активному творенні (В. Давидов, О. Ткаченко). Сучасні психологи (зокрема, Я. Пономарьов) підкреслюють, що в кожній людині закладена здатність до творчості. Акцент у XXI ст., як зазначає I. Лапшина, ставиться «не стільки на вихованні особистості, здатної до оригінальних проявів, скільки до характеру творчих проявів. Вони повинні бути ініціативними і незалежними від зовнішніх обставин, не спонукатися батьками чи вчителями, а мати самостійний характер» [4, с. 109].

Творчість школярів проявляється у діяльності, що пов’язана із засвоєнням нових знань, а результат такої творчої діяльності характеризується суб'єктивною новизною (В. Моляко). Водночас, знання про світ, про об'єктивну реальність, здатність розв'язувати задачі, які вона висуває, набуваються тільки в процесі творчої діяльності. При цьому знання є не самоціллю, а засобом навчання з метою здійснення діяльності.

Отже, у процесі особистісно-креативного розвитку молодших школярів ми виділяємо діяльнісний підхід, який реалізовується в процесі навчання музики. Навчальна робота охоплює такі напрямки: набуття слухового та виконавського досвіду; формування вокально-хорових навичок, творчих навичок, зокрема, навичок імпровізації, розвиток образно-асоціативного мислення; розвиток естетичного смаку.

Розвиток естетичного смаку заслуговує на особливу увагу. Як відзначає

В. Степанов, естетичні потреби особистості виступають основним мотивом навчальної діяльності за умови іiі спрямування на свідоме та глибоке розуміння музичного мистецтва. Музично-естетичне спрямування навчання має охоплювати зміст усієї музично-творчої діяльності «від формування позитивної мотивації навчальної діяльності до створення власного творчого продукту» [13, с. 66].

Зважаючи на це, деякі науковці в процесі розвитку креативності виділяють особистісно-мотиваційний підхід (О. Шиман). Водночас, музична творчість дітей пов'язана з самостійними діями та уміннями оперувати відомими їм музично-слуховими уявленнями (Л. Степанова). Це дає можливість вченим виділяти особистісно-діяльнісний підхід, що грунтується на виявленні індивідуальних особливостей як суб' єкта пізнання, так і предметної діяльності (Т. Тихонова). Але, в будь-якому разі, створення умов для «різнобічного прояву і відповідного розвитку особистісних можливостей, наприклад творчих здібностей, а не формування особистості із заданими спроможностями» [12, с. 91], вимагає застосування особистісного підходу. 
Застосування особистісного підходу сприяє виявленню $\mathrm{i}$ розкриттю індивідуальності школяра та його особистісного потенціалу, дає можливість досягти у процесі навчання суб'єкт-суб'єктних взаємовідносин, яких потребує творчий розвиток особистості. Оскільки в його основі лежать теоретичні положення про розвиток особистості через становлення системи цінностей самосвідомості, суб' єктивності, через свободу самовираження, саморозвиток та самоорганізацію (М. Лук’янчук ), особистісно-креативний розвиток молодших школярів у процесі навчання музики потребує саме особистісного підходу.

Як уже зазначалося вище, спрямованість на розвиток естетичних орієнтацій визначає напрямок усієї педагогічної роботи з молодшими школярами: розвиток їх інтелектуальної та емоційної сфер, набуття культурологічного досвіду, досвіду музично-творчої діяльності, духовне становлення. Реалізація цього напрямку відбувається завдяки інтегрованому підходу до особистісно-креативного розвитку молодших школярів у процесі навчання музики, що співпадає з концепцією НУШ. Інтегроване навчання забезпечує отримання учнями цілісного уявлення про світ, вивчення кожного явища різнобічно, у різних аспектах, розв'язування творчих завдань та реальних проблем за допомогою знань з різних навчальних предметів.

У контексті нашого дослідження таке поєднання відбувається на інтегрованих уроках музики та мистецтва, які включають знання з усіх предметів естетичного циклу та інших предметів з метою їх систематизації і застосування у творчій діяльності. В умовах інтегрованого навчання завдяки взаємопроникненню й систематизації знань відбувається особистісно-креативний розвиток особистості, здатної бачити нове, особливе у буденному; створювати нове, оперуючи відомим; використовувати вже набуті знання в нових ситуаціях.

Висновки. Отже, основними методологічними підходами до особистіснокреативного розвитку молодших школярів у процесі навчання музики визначаємо діяльнісний, особистісний та інтегрований. Наступні наукові розвідки ми вбачаємо у розробці педагогічних умов, що сприятимуть ефективності означеного процесу.

\section{References}

1. Vygotskij L. S. Myshlenie i rech [Thinking and Speech]. Izd. 5, ispr. Moskva: Labirint, 1999. $350 \mathrm{p}$. 
2. Druzhinin V. N. Psihologiya obshih sposibnostej [Psychology general abilities]. SPb.: Piter, 2002. 368 p.

3. Kravets N. P. Tvorchyi rozvytok uchniv z osoblyvymy osvitnimy potrebamy yak odyn iz shliakhiv yikh sotsializatsii [The creative development of pupils with special educational needs as one of the ways of their socialization] // Topical issues of social pedagogy: Collective monograph. - CARICOM, Barbados, 2017. P. 79-99.

4. Lapshina I. N. Puti formirovaniya tvorcheskih sposobnostej mladshih shkolnikov na adaptacionno-igrovom etape obucheniya russkomu yazyku [Ways of forming creative abilities in elementary schoolchildren at the adaptation-game stage of teaching the Russian language] // Pedagogika formuvannya tvorchoyi osobistosti $u$ vishij $i$ zagalnoosvitnij shkolah: zb. nauk. pr. Zaporizhzhya: KPU, 2019. No.62. Vol. 1. Pp. 108-112.

5. Luk'yanchuk M. Rozvitok tvorchih zdibnostej molodshih shkolyariv: psihologopedagogichnij kontekst [Development of creative abilities in young schoolchildren: psychological and pedagogical context]. Pedagogichnij chasopis Volini: nauk. zhurnal. Luck. PP Ivanyuk V.P., 2016. No. 2 (3). Pp. 82-87.

6. Nova ukrayinska shkola: poradnik dlya vchitelya [The New Ukrainian School: directory for teacher] / za zag. red. N. M. Bibik. Kyiv: Litera LTD, 2018. 160 p.

7. Pet'ko L.V. Aktyvizatsiia tvorchoho rozvytku osobystosti uchniv yak faktor pedahohichnoi maisternosti vchytelia inozemnoi movy [Stimulation of students' creative development as a factor of pedagogical skill of a foreign language teacher]. Dyrektor shkoly, litseiu, himnazii: vseukr. nauk.-prakt. zhurnal / zasn. MONmolodsportu Ukrainy, NAPN Ukrainy, NPU imeni M.P.Drahomanova; holov. red. O.I. Vyhovska. 2010. No. 2. Pp. 99-103.

8. Petko L. V. Stymuliuvannia tvorchykh zdibnostei pidlitkiv zasobamy vtilennia obrazu kazkovoho personazhu [Stimulating the teenagers' creative abilities by means of embodiment of fairy-tale character's image] // Lialka yak znak, obraz, funktsiia: Mater. vseukr. nauk.-prakt. konf. «Druhi Marka Hrushevskoho chytannia» / za red. O.S. Naidena. Kyiv: VD «Stylos», 2010. Pp. 200-204.

9. Ponomarev Ya. A. Psihologiya tvorchestva [Psychology of creativity]. Moskva: Nauka, 1976. 303 p.

10. Savenkov A. I. Psihologicheskie osnovy issledovatelskogo obucheniya shkolnikov [Psychological foundations of students'research teaching]. Fizik : problemy prepodavaniya. 2007. No. 3. Pp. 14-24.

11. Stepanova L. P. Metodika rozvitku polifonichnogo sluhu molodshih shkolyariv na urokah muziki [Methods of development of polyphonic hearing of younger students at music lessons]: avtoref. dis. ... kand. ped. nauk : spec. 13.00.02 - Teoriya ta metodika muzichnogo navchannya. Kyiv, 2011. 20 p.

12. Shandruk S. K. Obgruntuvannya metodologichnogo pidhodu rozvitku profesijnih tvorchih zdibnostej majbutnih praktichnih psihologiv [Substantiation of methodological approach in development of professional creative abilities in future practical psychologists]. Scientific Journal «Science Rise» Psihologichni nauki. 2015 No. 8/1 (13). Pp. 90-93. 
13. Stepanov Volodymyr. Determination of theoretical and methodological principles of teaching multimedia arrangement of future Music teachers in the process of professional training. Intellectual Archive. - Toronto: Shiny Word.Corp. (Canada). 2018. (November/December). Vol. 7. No. 6. Pp. 61-70. (https://doi.org/10.32370/2018_11_8)

14. Kravets N.P. Creative activity of mentally retarded pupils at Literature lessons in the process of using literary texts in the classroom // Challenges and opportunities of scientific thought development: Collection of scientific articles. - GPG Publishing Group, Pretoria, South Africa, 2017.

15. Pet'ko Lyudmila. Developing students' creativity in conditions of university // Research: tendencies and prospects: Collection of scientific articles. - Editorial Arane, S.A. de C.V., Mexico City, Mexico, 2017. Pp. 272-276.

\section{Translation of the Title, Abstract and References to the Author's Language}

\section{УДК 373.3.016:78}

Хоу Імей. Основні методологічні підходи до особистісно-креативного розвитку молодших школярів у процесі навчання музики.

У статті актуалізовано значення особистісно-креативного розвитку молодших школярів у процесі навчання музики. Розглянуто основні методологічні підходи до особистісно-креативного розвитку молодших школярів у процесі навчання музики. Застосування особистісного підходу сприяє виявленню і розкриттю особистісного потенціалу школярів, встановленню суб'єкт-суб'єктних взаємовідносин. Відзначено, що творчість школярів проявляється у навчальній діяльності, тому для особистіснокреативного розвитку молодших школярів у процесі навчання музики важливе застосування діяльнісного підходу. Інтегрований підхід забезпечує розв'язування музично-творчих завдань за допомогою знань з усіх предметів естетичного циклу та інших навчальних предметів.

Ключові слова: навчання музики, креативність, розвиток, молодші школярі, особистісний підхід, діяльнісний підхід, інтегрований підхід.

\section{Література} $350 \mathrm{c}$.

1. Выготский Л. С. Мышление и речь. Изд. 5-е, испр. Москва: Лабиринт, 1999.

2. Дружинин В. Н. Психология общих способностей. СПб.: Питер, 2002. 368 с.

3. Кравець Н. П. Творчий розвиток учнів з особливими освітніми потребами як один із шляхів їх соціалізації // Topical issues of social pedagogy: Collective monograph. CARICOM, Barbados, 2017. P. 79-99.

4. Лапшина И. Н. Пути формирования творческих способностей младших школьников на адаптационно-игровом этапе обучения русскому языку. Педагогіка формування творчої особистості у вищій $і$ загальноосвітній школах: зб. наук. пр. Запоріжжя: КПУ, 2019. № 62. Т. 1. С. 108-112. 
5. Лук'янчук М. Розвиток творчих здібностей молодших школярів: психологопедагогічний контекст. Педагогічний часопис Волині: наук. журнал. Луцьк. ПП Іванюк В. П.. 2016. №2 (3). С. 82-87.

6. Нова українська школа: порадник для вчителя / за заг. ред. Н. М. Бібік. Київ: Літера ЛТД, 2018. 160 с.

7. Петько Л. В. Активізація творчого розвитку особистості учнів як фактор педагогічної майстерності вчителя іноземної мови. Директор школи, ліцею, гімназї̈: всеукр. наук.-практ. журнал / засн. МОНмолодьспорту України, НАПН України, НПУ імені М.П.Драгоманова ; голов. ред. О.І. Виговська. - 2010. № 2. С. 99-103.

8. Петько Л. В. Стимулювання творчих здібностей підлітків засобами втілення образу казкового персонажу //Лялька як знак, образ, функція: Всеукр. наук.-практконф. «Другі Марка Грушевського читання»/за ред. О.С Найдена. - Київ: ВД «Стилос», 2010. С. 200-204.

9. Пономарев Я. А. Психология творчества. Москва: Наука, 1976. 303 с.

10. Савенков А. И. Психологические основы исследовательского обучения школьников. Физика : проблемы преподавания. 2007. № 3. С. 14-24.

11. Степанова Л. П. Методика розвитку поліфонічного слуху молодших школярів на уроках музики : автореф. дис. ... канд. пед. наук : спец. 13.00.02 - Теорія та методика музичного навчання. Київ, 2011. 20 с.

12. Шандрук С. К. Обгрунтування методологічного підходу розвитку професійних творчих здібностей майбутніх практичних психологів. Scientific Journal «Science Rise». Психологічні науки. 2015 №8/1 (13). C. 90-93.

13. Stepanov Volodymyr. Determination of theoretical and methodological principles of teaching multimedia arrangement of future Music teachers in the process of professional training. Intellectual Archive. - Toronto: Shiny Word.Corp. (Canada). 2018. (November/December). Vol. 7. No. 6. Pp. 61-70. (https://doi.org/10.32370/2018_11_8 )

14. Kravets N.P. Creative activity of mentally retarded pupils at Literature lessons in the process of using literary texts in the classroom // Challenges and opportunities of scientific thought development: Collection of scientific articles. - GPG Publishing Group, Pretoria, South Africa, 2017.

15. Pet'ko Lyudmila. Developing students' creativity in conditions of university // Research: tendencies and prospects: Collection of scientific articles. - Editorial Arane, S.A. de C.V., Mexico City, Mexico, 2017. P. 272-276. 